\title{
THE HONOURABLE CHARLES ALLAN STUART
}

\section{W. Kenr Power, Q.C., LL.B., Legal Consultant, Calgary, Alberta}

"A man's achievements are to be measured by subtracting from what now exists that which he has added to what preceded him." This thought expressed by a very eminent American judge in his tribute to the greatest of English legal historians ${ }^{1}$ is especially applicable to the late Hon. Mr. Justice Stuart. His contribution to the architecture of the jurisprudence and higher educational system of this new province was of permanent importance. Two years after his appointment to the Supreme Court of the North-West Territories and one year after his appointment to the first Supreme Court of Alberta, he became in 1908 the first chancellor of the University of Alberta and retained that office until his all-too-early death in 1926, before he had completed his 62nd year. To his responsibilities as chancellor he brought the learning of a scholar (he had been McCaul gold medalist in classics at the University of Toronto) and the enthusiasm and painstaking interest of one who must have been conscious that he was assisting in building an enduring institution which would be a most potent force in the lives of the future residents of this new land of promise; and, what was equally important, he took a most kindly interest in the aspirations and activities of young people. He was a very human man, who won not only respect but affection. The many columns of tributes from colleagues and friends which appeared in the press on his passing are permeated with sincere expressions of a sense of personal loss.

As a judge, one who was a member of a very strong bench, he played a very influential role in moulding the jurisprudence of the western provinces and the constitution of his beloved Canada (he was born in Middlesex County in Ontario, and was a graduate, with honours, from Toronto University, and, in law, from Osgoode Hall). As one of his close associates said: "As a citizen he was first and foremost a Canadian who had visualized the future power and dignity of this nation. In our first [Alberta] legislature he was the mose distinguished representative." It is therefor not surprising that his favorite branch of legal study was Canadian constitutional law; and that he became known throughout the Dominion as one of our foremost authorities on that subject.

His judicial career is memorable especially for his participation in two of the landmarks in our legal history. He was the trial judge in the famous "Alberta and Great Waterways Railway case"." Although his reasons therein (which occupy the first pages of the first volume of W.W.R.) were not sustained by the Judicial Committee, some very eminent Canadian lawyers were of the opinion that this was one of the instances in which that august tribunal indicated its musunderstanding of the effect of the B.N.A. Act.

1Mr. Justice Frankfurter writing of Sir William Holdsworth, in "Of Law and Men", at p. 282. 2Rex. v. Royal Bank of Canada (1911) I W.W.R. 1, affirmed ibid. 1159, reversed 3 W.W.R. 994. 
He also wrote the leading reasons for judgment in another case of farreaching importance, Board v. Board ${ }^{3}$ which made clear the existence in Alberta of the English statute of 1857 respecting divorce, and also that the jurisdiction of the provincial Supreme Court was comprehensive and empowered it to grant decrees in such cases. Of the authorities bearing on that point, Lord Haldane said: "They are collected in the admirable opinion of Stuart, J. in the Supreme Court in the present case, from whose reasoning, as well as from the arguments employed by the other learned judges there, their Lordships have derived much assistance." "Admirable" was, indeed, the appropriate word. As a model of vigorous, lucid and concise English, and cogent reasoning, the writer can recall nothing in legal literature that surpasses these reasons for judgment. A brief example of the terseness of his style, which readers, both legal and lay, may find it helpful to keep in mind, was his statement in that case: "The question is not what Parliament meant or intended to say but what Parliament meant or intended by what it said." No law student can overvalue the importance of the ability to write clear and forceful English, and time spent on reading the reasons of Mr. Justice Stuart will be well repaid.

In truth it can be said that the welfare, in its best sense, of the past and present residents of this province, has been greatly advanced and enhanced because this scholarly, able, public spirited and foreseeing son of Ontario decided, after experimenting with life elsewhere, to make his home here. But a man's character and relations with his fellow men are of even more importance than his learning or mental faculties; and of him his colleague the late Mr. Justice Walsh [afterwards Lt. Governor] wrote: "But more important than that [his intellect, knowledge, etc.] we loved him for himself. He was essentially human. No kinder heart than his ever beat in the breast of man ... we his associates, bound to him by ties of real affection mourn the death of a man of kindly impulses and generous instincts who was our friend in the truest sense."

${ }^{3}$ [1918] 2 W.W.R. 633 affirmed [1919] 2 W.W.R. 940 (P.C.). 